\title{
Architectural and constructive concept of the historical residential development of St. Petersburg in the XVIII-early XX centuries
}

\author{
Svetlana Golovina ${ }^{1, *}$ \\ ${ }^{1}$ Saint Petersburg State University of Architecture and Civil Engineering, 190005 St. Petersburg, \\ Russia
}

\begin{abstract}
The most important stages of the formation of residential development are considered, the spatial and structural features of the construction of historical residential development of St. Petersburg in each period are identified. The organization of private plots, functional and spatial characteristics and design solutions of residential buildings are described. The typology of residential planning systems used at that time was clarified, design options and variants for using building materials in difficult geological conditions and taking into account the peculiarities of the local microclimate are shown. These characteristics are considered by the general system and are the basis for a comprehensive renovation of historical buildings in St. Petersburg.
\end{abstract}

\section{Introduction}

St. Petersburg is a city of not only famous urban ensembles, but also a magnificent "ordinary" residential development. It is the outstanding architectural qualities of each building with the integrity of the overall architectural appearance that largely determine the unique advantages of the entire historical development of the city. Overhauls of buildings with the loss of historical interiors, the demolition of so-called dilapidated buildings or the preservation of only front facade walls step by step lead to the physical destruction of buildings. There is a real danger to the whole unique architectural and urban heritage of St. Petersburg, the threat of losing the spatial and compositional perfection of its development and, most importantly, the material and structural basis of the uniqueness of the city. The first step in understanding the perfection of the material and structural basis of St. Petersburg is to study the history of its development. It is necessary to determine the stages of the formation of residential development, to identify the spatial and structural features of the construction of historical residential buildings of St. Petersburg in each period.

\footnotetext{
*Corresponding author: 79213348460@yandex.ru
} 


\section{Materials and Methods}

Since the beginning of the XVIII century, various types of architectural, planning and constructive solutions for residential development were successively formed on the territory of St. Petersburg within the framework of a single architectural and planning system. The starting point is the organization of private plots from the moment the city was founded, the development process of which directly influenced the formation of functional and spatial characteristics and space-planning decisions of development, which in turn influenced the design concepts for buildings. Next, it should be described what spatial and planning characteristics of residential buildings correspond to each period, what structural concepts and materials were used in each era. All these characteristics should be considered in the overall system as a combination of a single whole. The determination of the stages of the formation and development of the material and structural system of residential historical buildings will subsequently help develop proposals for comprehensive renovations that take into account the value of the historical architectural and structural characteristics of the reconstructed object.

\section{Results}

The first stage - 1712-1730s. In the period from 1712 to 1716 , there were two main types of urban areas: line and firewall types of residential development. Residential buildings of model projects of D. Trezzini were built according to the type of line building. Singlestorey (wooden, hut, brick) houses on 4-5 and 15 axes with a front building along the red line with a separate main house, garden buildings, and a regular garden. On the sides of the house, there are a fence and an entrance gate, in the depths of the plot, there are farm buildings. In less critical places, the development was carried out in the form of a line with fire breaks. Firewalls can be seen in the concept to the model house designed by J.-B.-A. Le Blond in 1716. The two-story brick house of Le Blond with seven axes on the basement, with a high attic roof with changes, was an example of a firewall brick building on the main streets and embankments of St. Petersburg.

The sizes of the plots were regulated. At first, the width of the plots along the banks of the Neva and canals, on the main streets with "stone chambers in two dwellings" (two floors) was 6-8-10 sazhens $(12.8-17.0-21.3 \mathrm{~m})$, in the ordinary buildings with wooden structures - 7-10 sazhens $(7.9-21.3 \mathrm{~m})$. Then, fsince 1724 , plots became 5-8-10 sazhens wide (10.6-17.0-21.3 m) and 50-70 $\mathrm{m}$ long - half the quarter width.

Along with the regulation of the plots, the structures of walls (brick, half-timbered, wooden - 1714-1716), ceilings (1718), roofs (tile, wall, lath, earth - 1714, 1718), foundations (piles, sills, stone, brick) were also legally regulated [1]. The construction was carried out with the widespread use of local building materials. A hut house was used as a model. Only residential buildings for the nobility were made of stone, and the mass residential development of this stage was completely wooden and did not survive due to its fragility. During this period, a transition was made from the traditional Russian irregular development of neighborhoods to the unique regular brick, hut or wooden clearly regulated development with front buildings along the red lines, which became the basis for the development of the city.

The second stage - the end of the 1730s - 1750s. This is the stage of development according to the "tested" projects of M. Zemtsov, which were developed on the basis of the "model" projects of D. Trezzini and J.-B.-A. Le Blond for urban brick and wooden buildings. From the Admiralty to the Moyka river were built in two apartments on the cellars, from the Moyka River to the future Yekaterininsky Canal - in one apartment on the cellars, then - in one apartment. The height of the basement was increased due to constant 
floods (one foot higher than the flood level of 1721) [2]. In the center of the city, for example, in the area of the future Millionnaya Street, houses were built according to the firewall type of construction, the entrance to the courtyard was through a gate in the building. On Nevsky Prospekt, the houses stood with a gap, an "incomplete" line building. The buildings were constructed with front buildings along the red lines, without setback. The only exception was the development of the suburban area.

Since 1738, new dimensions of the plots were proposed - with a width of at least 12 sazhens $(25.6 \mathrm{~m})$ and a length of no more than 25 sazhens $(53.25 \mathrm{~m})$. "Large" plots - 20 sazhens wide $(42.6 \mathrm{~m})$ wide, "medium" plots -15 sazhens wide $(31.95 \mathrm{~m})$ and "small" plots - 10 sazhens wide $(21.3 \mathrm{~m})$ were accepted for mass execution. The length of these plots is half the width of the quarter.

The geological and climatic conditions of St. Petersburg, as well as constant fires (especially in 1736-1737), floods dictated a constant search for improving the building and structural system of residential buildings [3]. Brick and stone for walls were largely introduced, firewalls became mandatory, ceilings over basements and first floors were made vaulted with stone, the roofs began to be covered with iron or tile, and the roof structures were made without changes [4].

Walls - brick with mortar. The size of the bricks made at state-owned factories is $280 \mathrm{x}$ $140 \times 70$ in raw, the brick of private factories was made in non-standardized sizes. The grade of the brick is iron ore, red and salmon with a large percentage of output of iron ore and salmon brick. Exterior finish - lime plaster with painting and the use of gypsum parts. Overlap of openings - voussoir, flat and arched lintels. Filling of window openings wooden, with small divided glazing. Socles - rubble and plaster. Cornices - brick, brick on a coping. Ceilings - wooden beams with grooves, ledgers and ledger strip. Roof - a wooden rafter system with a roof made of sheet metal, tiles and boards.

The third stage - the 1760s - 1790s. At the beginning of this period, a perimeter firewall development began to form with a single composition of the front and yard buildings and with an average height of front houses of 2-3 floors and yard buildings (outbuildings) of 1-2 floors. This type of development has become main in the central areas of the city. On the periphery and on the outskirts, the buildings of the previous type remained. At the same time, the depth of the front wing almost remained the same - 5 meters, but side wings appeared with a room depth of 3-4 meters. The front houses began to be built over the full width of the plot, the entrance to the yard was designed as an arched passage on the first floor along one of the side axes of the building. The front house was residential with a main floor. The courtyard outbuildings were multifunctional - stables, woodsheds, services were on the ground floor, and housing above them. Yard outbuildings were set along the land survey boundaries of the plot with a setback from the main house (or a passage). During this period, the appearance of several yards on the plot is observed a transverse yard facility was built (if the length of the plot allowed it) on the condition that the yard was no less than $10 \times 20 \ldots 12 \times 25$ sazhens $(21.3 \times 42.6 \ldots 25.6 \times 53.3 \mathrm{~m})$. The height of the front house reached three floors, the yard outbuildings - 1-2 floors.

In the $1760 \mathrm{~s}$, the function of the first floor has changed, which entailed changes in the space-planning parameters. The area of the window increased - the first showcases appeared and, as a result, the depths of the premises increased slightly. The placement of internal wings along the land survey boundaries formed the parameters of their further development - in one span, with a small width of the premises, and a mono-pitched roof.

Walls - brick with mortar. The size of the brick was $6 \times 3 \times 1.5$ vershoks. Grade - iron ore, red and salmon. Due to the improvement of brick manufacturing technology, the proportion of red brick output increased. Exterior finish - lime plaster with painting and widespread use of finished gypsum products. Overlap of openings - voussoir, flat and arched lintels. Filling of window openings - wooden, with a larger deviation of glazing than 
in the first period, with an increase in the quality of glass. It became possible to glass large windows on the ground floor designed for shops and cafes. During this period, hydraulic solutions were widely used for laying socles and cornices. Socles were made of rubble and plaster. Cornices - brick on a coping - for front facades, brick - for yard facades. Ceilings brick, vaulted and wooden on beams with ledger strips. Roof - a wooden rafter system with a roof made of sheet roofing iron. In ceilings and roofs, iron fasteners and embedded parts in the walls were widely used.

The fourth stage - 1801-1860. The stage of the beginning of the development of tenement housing construction through repeated reconstruction of former manor houses and the advent of tenement housing construction itself. The renting of apartments and rooms, which was widely used by the general population, was becoming increasingly important. Different types of permanent and temporary housing were built for different ranks of the population.

During this period, a system of functional yards appears. Private plots were built up with brick buildings in the firewall perimeter system with one or several ordered yards on the plot, with the front residential building already predominantly of 3-4 floors along the red line with a "solid facade" [5] and adjacent yard residential and service buildings of 4-5 floors located along the land survey boundaries. Yards are geometrically ordered with restrictions on the size of $5 \times 6$ sazhens $(10.65 \times 12.8 \mathrm{~m})$, functional yards appeared. The plot itself could be at least $10 \times 20$ sazhens $(21.3 \times 42.6 \mathrm{~m})$.

Along with the regulation of the plots, attempts were made to regulate the facades. The facades were supposed to be symmetrical, the axis of the facade was formed by a window, an odd number of window openings. The dimensions of the window openings - a height of at least $21 / 4$ arshins $(1.6 \mathrm{~m})$, a width of at least $11 / 4$ arshins $(0.89 \mathrm{~m})$, walls are narrower than the width of the windows, the height from the top of the windows to the roof, including the cornice, not less than $0.89 \mathrm{~m}$. For small buildings, the height of the window is 2 arshins $(1.42 \mathrm{~m})$, width -1 arshine 2 vershoks $(0.8 \mathrm{~m})$, with the width of the walls not less than the width of the windows. The height of the windows above the ground is at least two $\operatorname{arshins}(1.42 \mathrm{~m})$, the distance from the windows to the roof is at least one $\operatorname{arshin}(0.71 \mathrm{~m})$.

A variety of typical schemes of model residential buildings of this time can be divided into several groups: one-story houses with 1, 3, 5, 7 windows (along the length of the building); houses with mezzanines in 5, 7, 9 windows; two-story houses with 3, 5, 7, 9, 11 windows; three-, four-story residential tenement houses; houses with shops on the ground floor.

During this period, the foundations of building regulation were laid. Height restrictions, the need to observe the width and depth of the private plots, the use of bricks and wood - all this created a very specific type of development with 3-4-storey front wings, firewall construction with a "solid facade" and the depth of the premises of the front wings up to 5-7 meters. The latter, in turn, created the prerequisites for increasing floor growth [6].

The fifth stage - the 1860-1890s. The stage of the final formation of tenement housing construction. The beginning of the stage was marked by the abolition of serfdom, the outflow of population from villages and the rapid population growth in the city, including in St. Petersburg. In this regard, there was an urban densification. The height of the building according to the Highest Decrees and the new editions of the Building Code of St. Petersburg from the sidewalk to the cornice is not more than the width of the street, or not higher than 11 sazhens $(23.4 \mathrm{~m})$. If the building is being built on the corner of two different streets, the height is no more than the widest of them. The lowest building height during this period is 5.5 arshins $(3.9 \mathrm{~m})$. The roof height of the front facade is $2 / 7$ of its width. If the building is no more than four sazhens wide $(8.5 \mathrm{~m})$ - up to $1 / 3$ of the building's width. Wooden stairs were forbidden, balconies and lattices should have been iron or cast iron. Floor height of at least 3.5 arshins $(2.49 \mathrm{~m})$. The distance between the brick buildings on 
the plot of at least two sazhens $(4.26 \mathrm{~m})$. It is allowed to divide the plots into several new ones, subject to the organization of separate exits to the street, with direct passages from plots to streets with a driveway width of at least $3.2 \mathrm{~m}$.

In the second half of the 19th century, the government moved to the regulation of the "negative" nature: by establishing standards that determine what cannot be done, i.e. from regular state-controlled construction according to "model" projects to construction according to individual projects. Thus, it should be noted that the regulation has reached a new level and gave the architect sufficient space in the development of the facade. But spatial-compositional and spatial-planning parameters were dictated, of course, by the height restrictions, the size of the plot, and the need to increase the area of the front wings, their height and the development of the yard space.

The residential house held the main position in the complex of buildings and had the obligatory central axial composition of the facade. There are no outbuildings. The facade occupied the entire front of the street, "so that there would not be the slightest gap between the houses" [7]. In fact, one street facade was of artistic value. Attics are allowed if they do not increase the height of buildings, the roof slope is at least 45 degrees, the roof material is iron.

Walls - brick with mortar. The size of the brick was $6 \times 3 \times 1.5$ vershoks. Grade - iron ore, red and salmon. Due to the improvement of brick manufacturing technology, the proportion of red brick output increased. Exterior finish - painted lime plaster. Overlap of openings - brick arched lintels, discharging arches over window openings. Filling of the window openings - wooden, with a larger deviation of glazing than in the first period, with an increase in the quality of glass and the appearance of shop windows. Socles - rubble made of limestone, slabs made of limestone, granite, less commonly - plaster. Cornices brick on a coping using flat, tee-shaped and screw iron. Ceilings - using bricks, softwood logs, iron rails, structural iron. Roof - a wooden rafter system with a roof made of sheet roofing iron [8].

Structural iron and embedded parts in walls, ceilings and roofs had a widespread use. The main method of connecting individual metal elements was riveting, completely displacing the forge method of connection.

The sixth stage - 1900-1917. This is the period of the production boom, the development of the engineering and metallurgical industries, and, as a consequence, the period of the construction boom. The stage of new functional development of residential development. In the period under consideration, systems of large yard ensembles of ribbon building arise, with several courtyards, courts of honour, large entrance arches, with a system of attached and separate courtyard outbuildings. The height of buildings is usually almost 5-6 floors and reaches seven. Mass reconstruction of the existing building is being carried out with its compaction and increase in the number of floors in the plots. Methods of reconstruction - finishing construction and heightening of existing buildings, or its complete demolition and construction of new buildings.

The space-planning parameters of this period are an increase in the size of buildings and the depths and heights of the premises. The absolute dimensions of the space-planning parameters of the front wing are growing by increasing its number of floors to the limits of the height restrictions, increasing the width of the front building to 16-18 meters, the predominant use of structural schemes with longitudinal load-bearing walls, increasing the depth of rooms to 8-9 meters and their height to $5-6$ meters [9]. The greatest parameters were achieved by the front enfilades of the front buildings. The mass distribution of such sizes of premises is confirmed by the presence of special resolutions of the St. Petersburg City Council at the beginning of the XX century, which established these parameters in the form of regulatory documents. 
Walls - brick with mortar. The size of the brick was $6 \times 3 \times 1.5$ vershoks. Widespread introduction of facing, radial brick. Industrial manufacture of facade decoration details with the development of their structural solutions. Exterior finish - lime plaster with painting retained its importance. However, facing with natural stone, facing brick, a combination of natural stone, plaster, majolica has been widely used. Overlap of openings - brick arched lintels, discharging arches over window openings. Lintels with the use of iron and rolled steel received a certain development. Filling of window openings - wooden, often without binding - a wide distribution of shop windows. The use of Portland cement for laying socles and cornices. Frequent use of full stone facing [10-14].

Socles - stone, mostly veneer. At the end of the period, Portland cement is used for laying socles and cornices. Cornices - along with brick with a coping, iron-stone cornices were used. Ceilings - rolled steel, at the end of the period, rolled steel and reinforced concrete. Roof - a wooden rafter system with the introduction of attic-type structures, roofing from sheet roofing iron.

It can be seen from the foregoing that the six stages of development of the architectural and constructive development of the residential development of St. Petersburg have characteristics distinct from each other both in urban planning, in spatial and space, and in a constructive sense. On the other hand, all six stages describe a continuous and consistent path of development of the city's architecture.

\section{Discussion}

The specific dates of the beginning and end of periods remain debatable. In the work, they coincide with the time of the change of the reign of emperors, which led to significant changes in the political and economic life of Russia.

The relationship between space-planning and style characteristics of residential buildings requires additional development. The first two periods belong to the Baroque period, the next two periods - to classicism, the last two ones - to eclecticism and art nouveau. This issue should also be considered in further studies on the development of methods for the restoration and renovation of residential buildings.

\section{Conclusions}

The process of forming the functional-spatial and spatial-planning characteristics of residential development in St. Petersburg includes six stages. From stage to stage, the formation of an ultra-dense perimeter firewall development took place, which is a distinctive feature of St. Petersburg.

These stages are characterized by a certain duality. On the one hand, there was a high stability of the building system for the load-bearing frame of a building with a predominance of brick and wood; the introduction of iron, cast iron and steel occurred in emergency. On the other - the vigorous development and use of new materials in that part of the construction system, which is associated with the formation of building facade elements.

As a result of the analysis of the architectural and constructive solution of the historical residential development, a set of characteristics is obtained for each period, which are proposed to be used in the reconstruction of historical buildings. 


\section{References}

1. S. V. Sementsov, Urban development of St. Petersburg in the XVIII - early XXI century. The development of the territories near the Neva river before the foundation of St. Petersburg. The development of St. Petersburg in the XVIII century (SPb., SPbGASU, 2011)

2. S. V. Sementsov, S. G. Golovina, The history of the development of structures of buildings of historical residential development using the example of St. Petersburg (SPb., SPbGASU, 2012)

3. R. A. Mangushev, A. I. Osokin, Geotechnics of St. Petersburg (SPb., ASV, 2010).

4. E. Vozniak, A. Butyrin, E3S Web of Conferences 91, 05016 (2019) DOI: https://doi.org/10.1051/e3sconf/20199105016

5. P. N. Stolpiansky, Old Petersburg. The history of building materials (Petersburg, 1915)

6. A. L. Punin, Architecture of St. Petersburg in the mid-XIX century (Lenizdat, 1990)

7. Code of state improvement rules. Code of railway, construction and fire institutions and rules, 177-258 (St. Petersburg, 1842)

8. D. D. Sokolov, Course of civil architecture (SPb., 1883)

9. N. I. De Rochefort, Illustrated Boundary position. The allowance for the preparation and verification of estimates, design and execution of work (SPb., 1913).

10. L. Ya Burak, Technical examination of residential houses of the old development (Stroyizdat, 1977)

11. 2nd international conference on green building, materials and civil engineering, GBMCE 2013 (2013).

12. M. Chang, J. Zhao, Ekoloji 28(107), 3375-3382 (2019).

13. M. Khairi, A. Jaapar, Z. Yahya, IOP Conference Series: Materials Science and Engineering 271(1) (2017). DOI:10.1088/1757-899X/271/1/012030

14. N. Kozlova, Journal of Architecture and Urbanism 42(1), 52-62 (2018). DOI:10.3846/jau.2018.1842 